\title{
Crosstalk Among Circadian Rhythm, Obesity and Allergy
}

\author{
Kanami Orihara ${ }^{1,2} \mathbb{D}^{-}$, Atsushi Haraguchi ${ }^{1}(\mathbb{C}$ and Shigenobu Shibata $1, * \mathbb{C}$ \\ 1 Laboratory of Physiology and Pharmacology, School of Advanced Science and Engineering, \\ Waseda University, Shinjuku-ku, Tokyo 162-8480, Japan; orihara.k.ab@m.titech.ac.jp (K.O.); \\ hmar.h@fuji.waseda.jp (A.H.) \\ 2 School of Life Science and Technology, Tokyo Institute of Technology, Yokohama 226-8501, Japan \\ * Correspondence: shibatas@waseda.jp; Tel.: +81-3-5369-7318
}

Received: 10 January 2020; Accepted: 5 March 2020; Published: 10 March 2020

\begin{abstract}
The circadian clock system works not only as a cellular time-keeper but also as a coordinator for almost all physiological functions essential to maintaining human health. Therefore, disruptions or malfunctions of this system can cause many diseases and pre-symptomatic conditions. Indeed, previous studies have indicated that disrupted clock gene expression rhythm is closely related to obesity, and that allergic diseases can be regulated by controlling peripheral clocks in organs and tissues. Moreover, recent studies have found that obesity can lead to immune disorders. Accordingly, in this review, we assess the connection between obesity and allergy from the point of view of the circadian clock system anew and summarize the relationships among the circadian clock system, obesity, and allergy.
\end{abstract}

Keywords: circadian clock system; obesity; metabolic system; immune system; allergy

\section{Introduction}

Almost all plants and animals live in response to 24-hour cycles of the light-dark environment generated by the rotation of the earth. However, even in an environment that has no light-dark changes and no time information, we live under an approximately 24-hour cycle. This rhythm is known as a circadian rhythm. The circadian clock system generates the circadian rhythm and modulates the sleep-wake cycle, body temperature fluctuation, neural activity, and hormone secretion rhythm, all of which enable the body to function in response to a 24-hour cycle [1].

The circadian clock system consists of transcriptional-translational negative feedback loops between clock genes. Period1/2 (Per1/2), Cryptochrome1/2 (Cry1/2), Bmal1 (Brain and muscle arnt-like protein 1), and Clock (Circadian locomotor output cycles kaput) are the main componential genes of the core loop involved in the creation of an approximately 24-hour period. CLOCK heterodimerizes with BMAL1, and CLOCK:BMAL1 heterodimers act as transcriptional promoters for Per and Cry through binding with the specific promoter sequence known as the E-box. Per and Cry mRNAs then translocate from the nucleus to the cytoplasm and are translated into PER and CRY proteins. PER and CRY form a heterodimer and return to the cytoplasm. PER:CRY heterodimers then act to inhibit Per and Cry transcription through binding to CLOCK:BMAL1 heterodimers that bind with the E-box. As a consequence, Per and Cry mRNA and protein levels show circadian changes [2]. Moreover, other feedback loops exist alongside this core loop. In another loop, Retinoic acid receptor-related orphan receptor (Ror) and Reverse erythroblastosis virus (Rev-erb) are regulated by the core loop, and these proteins enhance and inhibit transcription of Bmal1, respectively, through binding to another specific ROR response element (RORE). Moreover, Rev-erb inhibits transcription of Clock through binding with the REV-ERB response element (RevRF). In addition to these loops, post-translational 
modifications, such as phosphorylation, ubiquitination, and subcellular trafficking, contribute to the maintenance of the circadian clock system by modulating the stability of the clock gene proteins [3].

In mammals, almost all cells of the body share the molecular mechanism described above. These clock gene systems are divided into central and peripheral clocks, depending on the organs in which they exist [4]. The central clock exists in the suprachiasmatic nucleus (SCN) of the hypothalamus, while peripheral clocks exist in almost all peripheral organs and brain regions other than the SCN. The central and peripheral clocks form a hierarchical system. In general, the central clock is entrained by environmental light, through the retinal-hypothalamic tract, for eliminating the difference between the environmental clock and the circadian clock. Subsequently, the central clock activates neural signals, hormonal signals, locomotor activity, and other pathways to adjust the peripheral clocks to the environmental clock [5]. Accordingly, environmental light is an essential factor for keeping the biological rhythm at $24 \mathrm{~h}$, because the period length created by the circadian clock system is longer than $24 \mathrm{~h}$. Indeed, the period length of the sleep-wake cycle was shown to be $24.5-25 \mathrm{~h}$ for participants living without sunlight and time information [6]. Moreover, previous studies showed that SCN-lesioned mice or mice under light-light (LL) conditions, where the central clock is malfunctioning, showed arrhythmic locomotor activity and feeding rhythm. Besides, peripheral clocks in these mice showed different phases for each organ, and their amplitudes were lower than those in mice kept under usual light-dark (LD) conditions $[7,8]$. Taken together, these studies show that the central clock orchestrates other biological clocks and that environmental light is the only entrainment factor of the central clock.

While the central clock is entrained only by environmental light, peripheral clocks can be entrained by many stimuli, such as temperature, meal, exercise, and stress [9]. A previous study showed that delaying the timing of three meals a day (breakfast, lunch, and dinner) by 5-hours delayed the clock gene expression rhythm in adipose tissue in humans. This study also showed that the secretion rhythms of cortisol and melatonin, which are biomarkers for evaluating the rhythm of the central clock, remained unaffected [10]. Another study, which used RNA from the hair follicle cells in humans, demonstrated that nighttime exercise (from 20:00 to 22:00) delayed the phase of clock gene expression rhythm for 2 to $4 \mathrm{~h}$, as compared to that without exercise [11]. Studies in mice have shown that many environmental factors, such as restricted feeding (RF) during the inactive period, wheel-running exercise only during the beginning or end of the active period, and physical and psychological stress, affected the phase of peripheral clocks, but not the central clock [12,13]. Moreover, these studies in mice identified insulin and cortisol as the main entrainment factors when the peripheral clocks are affected by feeding, exercise, and stress [12,13]. Therefore, whereas the central clock is entrained only by the environmental light, the peripheral clocks are orchestrated by the central clock but also affected by external stimuli, including feeding, exercise, and stress.

In the circadian clock system, the clock genes regulate not only expression rhythm of themselves, but also the expression rhythm of clock-controlled genes (CCGs). The CCGs are involved in many physiological functions, such as metabolism, immunity, and other functions. Indeed, previous studies showed that CCGs represent approximately $10 \%$ of all genes in many organs [14]. Consequently, studies in humans showed that postprandial blood glucose levels in the evening are maintained at a higher level than in the morning [15]. Moreover, an additional study demonstrated that a late dinner increases the maximum of postprandial blood glucose levels compared with an early dinner [16]. In addition, circadian rhythms have been observed in the occurrence of various diseases, such as asthma, myocardial infarction, and depressive symptoms, due to the circadian rhythm of hormone secretion, neural activity, and other physiological functions [17]. Indeed, studies in mice revealed that glucose tolerance testing at the beginning or middle of the active period produced lower blood glucose levels than the idle period [18]. Other studies showed that food antigen exposure in the late inactive period caused more severe food allergy symptoms than in the late active period [19] and that salivary IgA secretion rhythm was abolished by SCN lesion [20]. Therefore, keeping an accurate circadian clock system is vital for maintaining normal physiological functions. 
In this review, we limit discussion to the mammalian circadian clock system and focus on the interplay among the circadian clock system, obesity, and allergy. Moreover, we discuss not only phenomenological studies in humans but also fundamental mechanisms using mice and other animal experiments. In doing so, we hope this review improves the understanding of these interactions.

\section{Circadian Rhythm in Obesity}

The increase in the number of people with obesity is a global public health concern, which poses a substantial socioeconomic burden. Furthermore, epidemiologic studies have indicated that obesity increases the risk of diabetes, insulin resistance, metabolic syndrome, and cardiovascular disease [21,22]. Many studies in humans have shown that obesity associates with disturbances of biological rhythms, such as those governing sleep and food intake. Additionally, studies have shown that people with obesity have delayed bedtimes and shorter sleep duration compared to healthy people. In one study, plasma melatonin circadian rhythm in people with obesity was disrupted, and no significant circadian rhythm was found [23]. In another study of mainly overweight women, there was a negative correlation BMI with urinary 6-sulfatoxymelatonin concentration at 09:00, which is a metabolite of melatonin and shows rhythm similar to melatonin secretory rhythm [24], suggesting that overweight women's melatonin rhythm might be disturbed. The reason is that serum melatonin and urinary 6-sulfatoxymelatonin show similar secretory rhythm. Moreover, nocturnal hyperphagia and morning anorexia, which were regarded as delayed food intake pattern, was observed in a group of obese women, which is characteristic of night eating syndrome [25]. In brief, obesity is involved in not only the malfunction of the metabolic system but also the disturbance of biological rhythms.

On the other hand, obesity is caused by a disrupted lifestyle rhythm, such as shift work and varying meal timings. In terms of shift work, previous human epidemiological studies indicated that shift work, especially the duration of shift work, is associated with an increased risk of obesity [26,27]. Regarding the timing of meals, studies showed that skipping the first meal of the day (breakfast) increases the risk of obesity [28,29], that the multivariable-adjusted odds ratio of obesity was even higher with a late dinner and bedtime snack than with skipping breakfast [30], and that subjects given 2000 calories in a single daily meal for a week showed greater body weight loss when this meal was given at breakfast rather than at dinner [31]. Shift work and varying meal timings not only are associated with the increased risk of obesity but also alter the biological rhythm. Previous studies have shown that nocturnal light exposure increased the secretion of insulin and GLP-1 after meals [32] and that the acute stimulation of night work for 4 days slowed down the increase in postprandial blood glucose levels and reduced insulin sensitivity [33]. Another study suggested that a positive correlation between body fat percentage and the percentage of calories consumed $4 \mathrm{~h}$ before dim light melatonin onset (DLMO; a biomarker for the beginning of the biological night) or sleep onset [34]. From these papers, a late food intake corresponded to the biological clock, independent of amount or content of food intake and activity level, would be associated with increased body weight and/or obesity. In addition to these effects of shift work and varying meal timings on metabolic parameter, Indeed, previous studies in humans showed that the shift work shifted the phase of clock gene expression rhythm and the levels and timing of melatonin production [35,36], and that delayed three meals (breakfast, lunch, and dinner) for 5-hour delayed clock gene expression rhythms in adipose tissue [10]. Taken together, evidence suggests that a disrupted lifestyle rhythm, such as that seen with shift work and varying meal timings, is a contributing factor to obesity, and obesity interacts closely with a disrupted lifestyle rhythm.

These interactions have also been observed in many studies in mice and rats. There are many rodent models of obesity and diabetes, such as ob/ob mice and $\mathrm{db} / \mathrm{db}$ mice, which are deficient in leptin and the leptin receptor, respectively, KK- $A^{y}$ mice, which are obese and diabetic mice independent of insulin, and high-fat diet (HFD) induced obesity (DIO; diet-induced obesity) model mice. Many previous studies have indicated that these obesity model mice show disruption of biological rhythms, such as locomotor activity rhythm, food intake rhythm, and clock gene expression rhythms. 
For example, obese ob/ob mice show a phase shift and decreased rhythmicity of the sleep-wake cycle and locomotor activity rhythm $[37,38]$, and the amount and amplitude of their locomotor activity and energy expenditure are decreased significantly compared with healthy mice [39]. Further, diabetic obese $\mathrm{db} / \mathrm{db}$ mice show no circadian rhythmicity in locomotor activity, and their REM duration in the inactive period is decreased, although their clock gene expression rhythm in central and peripheral clocks shows circadian rhythmicity [40,41]. Moreover, the changes in metabolic parameters, such as plasma glucose, insulin, liver glycogen, and hepatic glycogen synthase and phosphorylase activities, in diabetic obese $\mathrm{db} / \mathrm{db}$ mice may be caused by changes in daily rhythm rather than by absolute changes [42]. Also, obese and diabetic KK- $A^{y}$ and DIO mice show attenuated expression rhythm of clock genes and downstream target genes of clock genes in the liver and central nervous system [43-46]. Thus, these studies indicate that obese mice, regardless of model, show disruptions of biological rhythm and that some types of obese model mice dysregulate their clock gene and CCG expression rhythms.

Contrarily, other studies have indicated that disrupted biological rhythm, caused by altered light conditions, HFD, or clock gene deficiency, increases the risk of obesity. In rats, the chronic advance of the light period increased appetite, and decreased metabolism and energy expenditure, while promoting significant alterations in neuropeptides, lipid metabolism, and inflammation [46]. Moreover, feeding mice with an HFD increased food intake during the inactive period and decreased food intake during the active period, leading to a reduction in food intake rhythmicity. These effects are caused by activated microglia that promote hypothalamic inflammation [47]. Besides, this diet decreased locomotor activity during the day and reduced the synchronization to light $[48,49]$. Previous studies have also suggested that the effects of HFD on biological rhythm are due to disturbed clock gene and CCG expression rhythm, which may be caused by disrupted food intake rhythm. Indeed, it has been demonstrated that feeding with HFD shifts the phase of clock gene and CCG expression rhythm in many peripheral organs, disturbs the phosphorylation rhythms of the metabolic regulators CREB and S6, impairs CLOCK:BMAL1 recruitment, and promotes activation of pathways through the transcriptional regulator PPAR $\gamma$ [50-52]. On the other hand, several papers suggest that mutations or deletions of clock genes are related to dysfunctional energy metabolism. Cry mutation mice show dysfunctions in insulin secretion and hyperglycemia [53]. In Bmal1-KO (knockout) mice, disorders of lipid metabolism, independent of food components, a high respiratory quotient, which indicates difficulty utilizing lipids as an energy source, and lower insulin secretion are seen compared to wild-type mice [54,55]. Moreover, studies of these mice have indicated that PEPCK (phosphoenolpyruvate carboxykinase) and GLUT2 (glucose transporter 2), which are involved in glucose metabolism, showed low expression levels and arrhythmic expression [56]. In Clock mutant mice, arrhythmicity of food intake and dysfunction of the metabolic system are seen [57]. Moreover, these mice show severe hypoglycemia after insulin injection due to impaired gluconeogenesis [58]. Liver-specific Rev-erb $\alpha$ and $\beta$ double KO mice show arrhythmic expression of Ppar $\alpha$, which is involved in $\beta$-oxidation of fatty acids [59]. Thus, disruption of the circadian clock system, caused by light conditions, HFD, and gene deletion, interacts with impairment of the metabolic system, leading to obesity.

\section{Obesity and Allergy}

Obesity reportedly causes an increase in the levels of inflammatory mediators, potentially leading to immune disorders. In the obese state, the levels of plasma adiponectin, an anti-inflammatory adipokine, are low, thus enabling the natural onset of inflammation [60]. Leptin and adiponectin are adipokines secreted by white adipose tissue and are known to be related to obesity and involved in glucose and lipid metabolism. Leptin, a hunger-inhibiting hormone predominantly made by adipocytes, is a mitogen factor for keratinocytes that also promotes fibroblast proliferation and positively correlates with body fat and body fat mass [60,61]. A study conducted in the United States of America revealed a positive correlation between BMI and total IgE levels in children aged 2 to 19 years old [60]. Interestingly, this study showed a relationship between CRP and total IgE levels with age-adjustment, which was also confounded by BMI [60]. Since obesity is associated with atopy, 
reflecting an inflammatory state, it may be correlated with food allergies [62]. Although it is a rather small study, one of the recent cohort studies with 164 children showed that obesity in girls at 2 years of was highly correlated with increased risk of asthma, with odds ratio 12.14 [63]. In adult study, 9,888 Japanese subjects study reported that obese significantly increases a risk of late-onset asthma only in women [64]. Meta-analysis of 18 children-subjected articles revealed that overweight or obese showed 1.30-fold increase in a risk of childhood asthma, and 1.90 for wheeze [65]. Another meta-analysis with 13 studies showed a positive correlation with 1.47 odds ratio between abdominal obesity and asthma [66]. Taken together, these studies have suggested that a higher prevalence of asthma is observed among obese and overweight adults and children, who are also at risk of increased severity and a worse prognosis [39,63-67]. However, precise mechanism of obesity causing asthma in children are still not clear, while late-onset asthma is mostly neutrophil-predominant and non-IgE-mediated, which shows increased levels in adipokines [68]. Moreover, a body mass index exceeding $30 \mathrm{~kg} / \mathrm{m}^{2}$ is associated with a $92 \%$ increased risk of developing asthma [69]. Furthermore, gastric bypass surgery was shown to significantly improve airway hyperresponsiveness in obese individuals with asthma who had normal serum IgE levels, but not in those with elevated IgE [70]. Several large-scale studies have reported that obesity positively correlated with allergic rhinitis (AR) and chronic rhinosinusitis (CRS) in both adults and children [61]. Additionally, a Spanish study showed a positive relationship between BMI and the severity of atopic dermatitis (AD) [66]. Further, although within the standard range, total cholesterol levels in patients with $\mathrm{AD}$ were higher than those in a healthy group, and were found to be yet higher in cases of severe $\mathrm{AD}$ [71]. Although skin dryness is one of the risk factors for $\mathrm{AD}$, contrasting results have been reported regarding transepidermal water loss (TEWL) and obesity. A significant positive correlation was reported between BMI and TEWL [72]. Additionally, increased TEWL was observed in obese children [73], while one study showed decreased TEWL in obese individuals [74]. The authors attributed this result to the role of adipokines and leptin [74].

So far, we have shown evidence of the positive correlation between obesity and allergic diseases. Interestingly, a study showed that the prevalence of AR/CRS and AD was higher in obese individuals than in those with asthma and food allergies [61]. These phenomena can be partially explained by interleukin (IL)-17 involvement. Anti-IL-17 monoclonal antibody treatment (Secukinumab) is an available option for the treatment of psoriasis, and it has shown a better, more rapid response in patients with a healthy BMI than overweight $(B M I \geq 25)$ patients [75]. This result suggests that IL-17 neutralization is less effective in obese patients because of obesity-mediated inflammation. Additionally, allergic diseases with higher involvement of type 3 inflammation (IL-17-related response) may show a stronger correlation with obesity. This observation is supported by the failure to induce obesity in IL-17 receptor A (IL-17RA) knockout mice [76].

In animal studies, obese mice were shown to develop allergic sensitization and severe airway eosinophilia with a smaller amount of allergen compared to lean mice. Obesity also decreased the threshold of allergic sensitization, as smaller amounts of allergen were sufficient to induce a comparable level of allergen-specific antibodies, as compared with lean mice [67]. Another study showed that HFD significantly increased mast cell accumulation in the intestine and enhanced intestinal permeability [77]. Interestingly, both of these effects are promoted by the induction of food allergy in these mice [77]. Microbiota transplantation experiments have also shown that HFD-associated microbiota enhanced susceptibility to food allergy, but did so independently of obesity [77]. Interestingly, the allergen-specific IgE levels of HFD-fed animals remained comparable to controls [77]. This finding suggests that IgE induces the increased intestinal mast cell response. Nevertheless, these studies suggest that obesity is a risk factor for developing allergic diseases, although the influence of atopic factors appears to be stronger.

\section{Circadian Rhythm in Allergy}

Recently, a large genome-wide association study identified RORA as one of the significant genes associated with asthma [78]. RORA encodes a member of the NR1 subfamily of nuclear hormone 
receptors that binds to ROREs in DNA as a monomer. Rora was reported to enhance Bmal1 transcription and play an essential role in maintaining a robust circadian rhythm [79]. In immunity, ROR $\alpha$ and ROR $\gamma$ are well known as key transcription factors for Th17 [80] and type 3 innate lymphoid cell [81] differentiation, both of which are important in chronic allergic diseases. ROR $\alpha$ is also an important factor for type 2 innate lymphoid cells (ILC2), and when it was knocked down together with IL-7R, ILC2-deficient mice were obtained [82]. Using this strain, the authors demonstrated a partial decrease of type 2 airway inflammation in an asthma model [82]. Collectively, both type 2 and 3 inflammation are under the control of $\operatorname{ROR} \alpha$, which plays a vital role in chronobiology by enhancing Bmal1 transcription. Together with BMAL1, ROR $\alpha$ is one of the major regulators of the circadian molecular oscillator. Therefore, the peculiar role of ROR $\alpha$ suggests that allergy is one of the responses under the influence of circadian homeostasis.

Recently, Spadaro et al. showed that histamine release from basophils oscillates and significantly fits a cosine curve in asthmatic patients, but not in healthy controls [83]. They also showed a less dramatic amplitude in daily cortisol rhythm in patients with asthma [83], suggesting the involvement of disrupted local molecular clocks in asthmatic physiology. However, a relatively small Korean study reported, interestingly, that CCGs from nasal mucosa in the right and left turbinates showed asymmetric expression levels [84]. The authors also found higher expression levels of these genes in AR patients, compared to healthy controls [84]. This suggests that the local molecular clock is dysregulated or shifted in the lesion site. Although a causality dilemma for this phenomenon is still not fully clarified, resetting the local clock can be one of the options to improve from this condition.

In humans, two single nucleotide polymorphisms (SNPs) of CLOCK were reported to enhance the risk of overweight or obesity by 1.8-fold [85]. Another study of CLOCK SNPs reported that three SNPs were associated with plasma cytokine levels, especially IL-6, adiponectin, and CCL2/MCP-1 [86]. Separately, variable number tandem repeats (VNTRs), such as 86 bp repeats in IL-1 receptor antagonist (IL-1RA) intron 2 and $70 \mathrm{bp}$ in IL-4 intron 3, were reported to be associated with obesity and adiposity in a Malaysian study [87]. Apolipoprotein ApoA-IV, found on high-density lipoproteins (HDL) cholesterol in serum, as well as in circulation, is known to have anti-inflammatory effects. ApoA-IV was reported to inhibit eosinophil chemotaxis towards CCL11/eotaxin and prostaglandin D2 (PGD2) via an NR1D1 (Rev-erb $\alpha$ )-dependent pathway [88]. The authors also examined the systemic effects of ApoA-IV using an asthmatic murine model, and showed a significant decrease in airway hyperresponsiveness with exogenous ApoA-IV administration [88].

Using mice, Ehlers et al. showed, interestingly, that, compared to controls, $\mathrm{Bmal}^{-/-}$or chronic jet lag mice developed severe acute viral bronchiolitis in response to Sendai virus and influenza A virus [89]. Similar results were also reported in myeloid cells of mice lacking BMAL1, which developed severe symptoms in an ovalbumin-induced asthmatic model [90]. Additionally, Nakamura et al. showed that a Clock mutation in mast cells caused a defect in FcERI, the high-affinity IgE receptor, expression, leading to an inadequate IgE-mediated degranulation [91]. They also reported that glucocorticoids inhibited IgE-mediated allergic reactions and increased PER2 levels, leading to a resetting of the local molecular clock in mast cells, both in vitro and in vivo [92]. Speaking of mast cells, circadian oscillations in mast cell degranulation were reported to be attenuated by inhibition of FcERI [92] or organic cation transporter 3 (OCT3) [93], both of which expression levels are temporarily regulated by Clock in their E-box motif in promoter region. These findings imply that mast cell functions in allergy can be regulated by recalibrating local molecular clocks.

\section{Conclusions}

Here, we summarize evidence from in vitro, ex vivo, and in vivo studies of rodents and humans, which show the interplay among the circadian clock system, obesity, and allergy (Figure 1). 


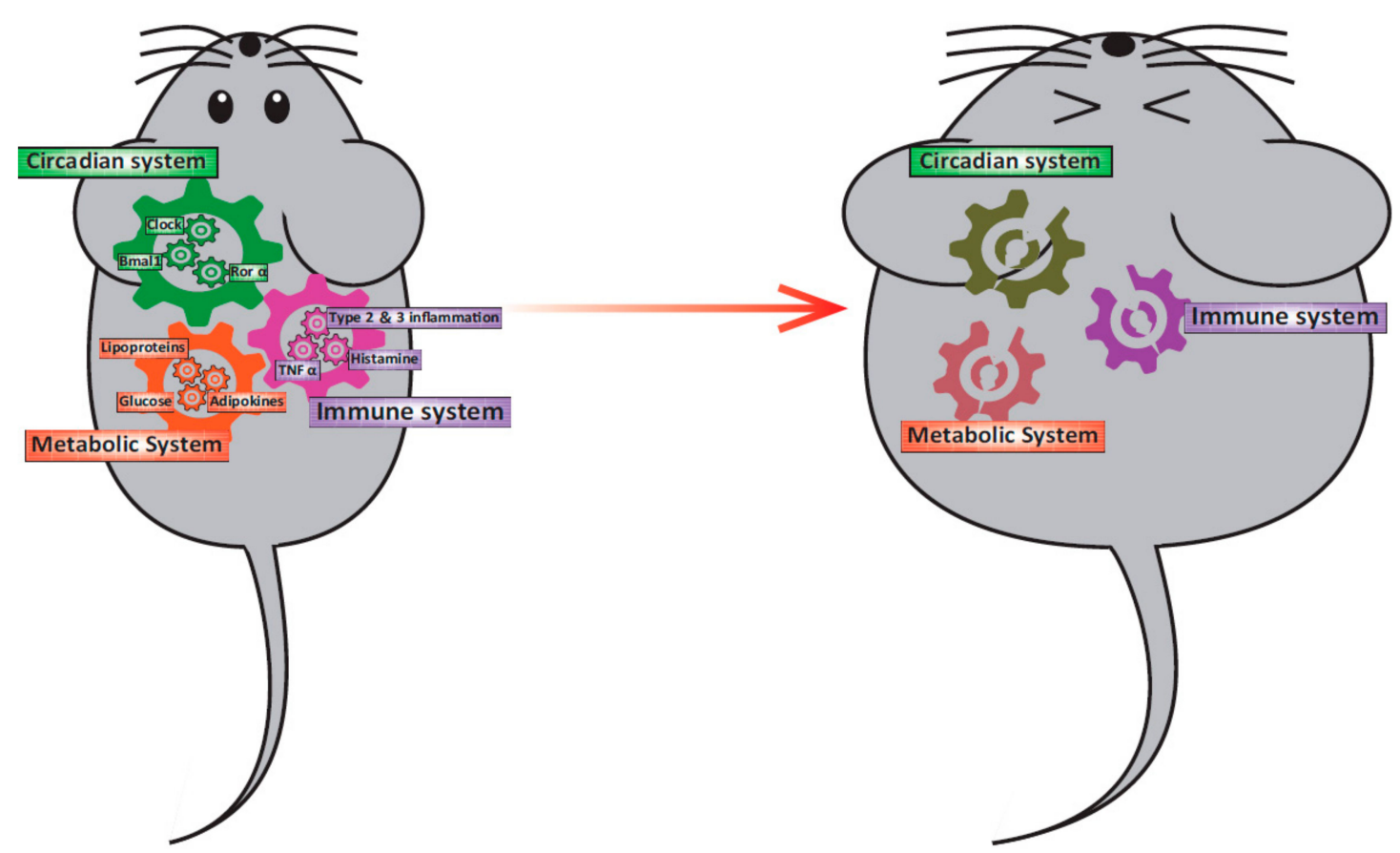

Figure 1. Relationship among the circadian clock system, obesity, and immunity. In a healthy state, the circadian clock system, the metabolic system, and the immune system interact and function normally. However, when one of the gears became out of position for some reason, other systems will be led to malfunction.

The reviewed studies suggest that the dysfunction of biological rhythms, irrespectively of the underlying cause, might lead to obesity. However, obesity also triggers arrhythmicity in clock gene expression and biological rhythms. Studies in mice have shown that time-restricted feeding (TRF) with HFD, independent of TRF timing, has an anti-obesity effect. This effect is mediated through the improvement of the disrupted clock gene and CCG expression and energy expenditure rhythms brought about by HFD feeding [50]. A recent study in humans confirmed that participants' body weight was reduced, and their sleep satisfaction was improved when eating duration, or the time from the first meal (breakfast) to the last meal (dinner or night snack), is restricted to $11 \mathrm{~h}$ [94]. Thus, regulating meal timings to correspond to one's biological rhythm would be helpful to attenuate obesity.

A growing body of evidence has reported on the relationship between circadian rhythm and allergy, but the understanding of the mechanisms underpinning this relationship is still limited. Interestingly, the phenomenon of nocturnal asthma has been discussed since the 1980s [95]. However, the molecular mechanisms by which the circadian system controls the pathophysiology of this condition remain to be elucidated. Recent studies in a variety of fields, including circadian system [96], and allergy [97,98] research, have focused on the microbiota. These reports suggest the importance of studying microbiota, in addition to examining probiotics and prebiotics, which may be key to investigating the unknown molecular mechanisms in these fields.

In this review, we assessed the connection between obesity and allergy from the viewpoint of the circadian system anew. Although we may not cover the whole field of disease phenotypes, we believe this review highlights the intimacy with which these three physiological aspects interact to maintain homeostasis. Further direct evidence to dissect the complex, mutual relationships between allergy and the circadian clock is required and may lead to a more in-depth understanding of the reciprocal interactions among the circadian clock, obesity, and allergy.

Funding: This research received no external funding.

Conflicts of Interest: The authors declare no conflict of interest. 


\section{References}

1. Golombek, D.A.; Rosenstein, R.E. Physiology of circadian entrainment. Physiol. Rev. 2010, 90, $1063-1102$. [CrossRef] [PubMed]

2. Buhr, E.D.; Takahashi, J.S. Molecular components of the Mammalian circadian clock. Handb. Exp. Pharmacol. 2013, 217, 3-27.

3. Mendoza-Viveros, L.; Bouchard-Cannon, P.; Hegazi, S.; Cheng, A.H.; Pastore, S.; Cheng, H.M. Molecular modulators of the circadian clock: lessons from flies and mice. Cell. Mol. Life Sci. 2017, 74, 1035-1059. [CrossRef] [PubMed]

4. Albrecht, U. Circadian rhythms and sleep-the metabolic connection. Pflugers Arch. 2012, 463, 23-30. [CrossRef]

5. Albrecht, U. Timing to perfection: the biology of central and peripheral circadian clocks. Neuron 2012, 74, $246-260$. [CrossRef] [PubMed]

6. Endo, T.; Honma, S.; Hashimoto, S.; Honma, K. After-effect of entrainment on the period of human circadian system. Jpn. J. Physiol. 1999, 49, 425-430. [CrossRef]

7. Chiesa, J.J.; Cambras, T.; Carpentieri, A.R.; Diez-Noguera, A. Arrhythmic rats after SCN lesions and constant light differ in short time scale regulation of locomotor activity. J. Biol. Rhythms 2010, 25, 37-46. [CrossRef]

8. Tahara, Y.; Kuroda, H.; Saito, K.; Nakajima, Y.; Kubo, Y.; Ohnishi, N.; Seo, Y.; Otsuka, M.; Fuse, Y.; Ohura, Y.; et al. In vivo monitoring of peripheral circadian clocks in the mouse. Curr. Biol. 2012, 22, 1029-1034. [CrossRef]

9. Shibata, S.; Tahara, Y.; Hirao, A. The adjustment and manipulation of biological rhythms by light, nutrition, and abused drugs. Adv. Drug Deliv. Rev. 2010, 62, 918-927. [CrossRef]

10. Wehrens, S.M.T.; Christou, S.; Isherwood, C.; Middleton, B.; Gibbs, M.A.; Archer, S.N.; Skene, D.J.; Johnston, J.D. Meal Timing Regulates the Human Circadian System. Curr. Biol. 2017, 27, 1768-1775. [CrossRef]

11. Okamoto, A.; Yamamoto, T.; Matsumura, R.; Node, K.; Akashi, M. An out-of-lab trial: a case example for the effect of intensive exercise on rhythms of human clock gene expression. J. Circadian Rhythm. 2013, 11, 10. [CrossRef] [PubMed]

12. Tahara, Y.; Shiraishi, T.; Kikuchi, Y.; Haraguchi, A.; Kuriki, D.; Sasaki, H.; Motohashi, H.; Sakai, T.; Shibata, S. Entrainment of the mouse circadian clock by sub-acute physical and psychological stress. Sci. Rep. 2015, 5, 11417. [CrossRef]

13. Sasaki, H.; Hattori, Y.; Ikeda, Y.; Kamagata, M.; Iwami, S.; Yasuda, S.; Tahara, Y.; Shibata, S. Forced rather than voluntary exercise entrains peripheral clocks via a corticosterone/noradrenaline increase in PER2::LUC mice. Sci. Rep. 2016, 6, 27607. [CrossRef] [PubMed]

14. Abele, S.H.; Meadows, K.E.; Medeiros, D.; Silver, A.C. Time is on the Immune System's Side, Yes it is. Yale J. Biol. Med. 2019, 92, 225-231. [PubMed]

15. Takahashi, M.; Ozaki, M.; Kang, M.I.; Sasaki, H.; Fukazawa, M.; Iwakami, T.; Lim, P.J.; Kim, H.K.; Aoyama, S.; Shibata, S. Effects of Meal Timing on Postprandial Glucose Metabolism and Blood Metabolites in Healthy Adults. Nutrients 2018, 10, 1763. [CrossRef]

16. Morgan, L.M.; Shi, J.W.; Hampton, S.M.; Frost, G. Effect of meal timing and glycaemic index on glucose control and insulin secretion in healthy volunteers. Br. J. Nutr. 2012, 108, 1286-1291. [CrossRef] [PubMed]

17. Muller, J.E.; Mangel, B. Circadian variation and triggers of cardiovascular disease. Cardiol. 1994, 85, 3-10. [CrossRef] [PubMed]

18. Mi, Y.; Qi, G.; Fan, R.; Ji, X.; Liu, Z.; Liu, X. EGCG ameliorates diet-induced metabolic syndrome associating with the circadian clock. Biochim. Biophys. Acta Mol. Basis Dis. 2017, 1863, 1575-1589. [CrossRef]

19. Tanabe, K.; Kitagawa, E.; Wada, M.; Haraguchi, A.; Orihara, K.; Tahara, Y.; Nakao, A.; Shibata, S. Antigen exposure in the late light period induces severe symptoms of food allergy in an OVA-allergic mouse model. Sci. Rep. 2015, 5, 14424. [CrossRef]

20. Wada, M.; Orihara, K.; Kamagata, M.; Hama, K.; Sasaki, H.; Haraguchi, A.; Miyakawa, H.; Nakao, A.; Shibata, S. Circadian clock-dependent increase in salivary IgA secretion modulated by sympathetic receptor activation in mice. Sci. Rep. 2017, 7, 8802. [CrossRef] 
21. Zhu, Y.; Hedderson, M.M.; Quesenberry, C.P.; Feng, J.; Ferrara, A. Central Obesity Increases the Risk of Gestational Diabetes Partially Through Increasing Insulin Resistance. Obesity (Silver Spring, Md.) 2019, 27, 152-160. [CrossRef] [PubMed]

22. Pagidipati, N.J.; Zheng, Y.; Green, J.B.; McGuire, D.K.; Mentz, R.J.; Shah, S.; Aschner, P.; Delibasi, T.; Rodbard, H.W.; Westerhout, C.M.; et al. Association of obesity with cardiovascular outcomes in patients with type 2 diabetes and cardiovascular disease: Insights from TECOS. Am. Heart J. 2019, 219, 47-57. [CrossRef] [PubMed]

23. Brambilla, F.; Fraschini, F.; Esposti, G.; Bossolo, P.A.; Marelli, G.; Ferrari, E. Melatonin circadian rhythm in anorexia nervosa and obesity. Psychiatry Res. 1988, 23, 267-276. [CrossRef]

24. Walecka-Kapica, E.; Chojnacki, J.; Stepien, A.; Wachowska-Kelly, P.; Klupinska, G.; Chojnacki, C. Melatonin and female hormone secretion in postmenopausal overweight women. Int. J. Mol. Sci. 2015, 16, 1030-1042. [CrossRef]

25. Stunkard, A.J.; Grace, W.J.; Wolff, H.G. The night-eating syndrome: a pattern of food intake among certain obese patients. Am. J. Med. 1955, 19, 78-86. [CrossRef]

26. Karlsson, B.; Knutsson, A.; Lindahl, B. Is there an association between shift work and having a metabolic syndrome? Results from a population based study of 27,485 people. Occup. Environ. Med. 2001, 58, 747-752. [CrossRef]

27. Shan, Z.; Li, Y.; Zong, G.; Guo, Y.; Li, J.; Manson, J.E.; Hu, F.B.; Willett, W.C.; Schernhammer, E.S.; Bhupathiraju, S.N. Rotating night shift work and adherence to unhealthy lifestyle in predicting risk of type 2 diabetes: results from two large US cohorts of female nurses. BMJ 2018, 363, k4641. [CrossRef]

28. Lazzeri, G.; Ahluwalia, N.; Niclasen, B.; Pammolli, A.; Vereecken, C.; Rasmussen, M.; Pedersen, T.P.; Kelly, C. Trends from 2002 to 2010 in Daily Breakfast Consumption and its Socio-Demographic Correlates in Adolescents across 31 Countries Participating in the HBSC Study. PLoS ONE 2016, 11, e0151052. [CrossRef]

29. Otaki, N.; Obayashi, K.; Saeki, K.; Kitagawa, M.; Tone, N.; Kurumatani, N. Relationship between Breakfast Skipping and Obesity among Elderly: Cross-Sectional Analysis of the HEIJO-KYO Study. J. Nutr. Health Aging 2017, 21, 501-504. [CrossRef]

30. Okada, C.; Imano, H.; Muraki, I.; Yamada, K.; Iso, H. The Association of Having a Late Dinner or Bedtime Snack and Skipping Breakfast with Overweight in Japanese Women. J. Obes. 2019, 2019, 2439571. [CrossRef]

31. Halberg, F.; Haus, E.; Cornélissen, G. From Biologic Rhythms to Chronomes Relevant for Nutrition. In Not Eating Enough: Overcoming Underconsumption of Military Operational Rations; Marriott, B.M., Ed.; National Academies Press: Washington DC, USA, 1995; pp. 361-372.

32. Gil-Lozano, M.; Hunter, P.M.; Behan, L.A.; Gladanac, B.; Casper, R.F.; Brubaker, P.L. Short-term sleep deprivation with nocturnal light exposure alters time-dependent glucagon-like peptide- 1 and insulin secretion in male volunteers. Am. J. Physiol. Endocrinol. Metab. 2016, 310, E41-E50. [CrossRef] [PubMed]

33. Bescos, R.; Boden, M.J.; Jackson, M.L.; Trewin, A.J.; Marin, E.C.; Levinger, I.; Garnham, A.; Hiam, D.S.; Falcao-Tebas, F.; Conte, F.; et al. Four days of simulated shift work reduces insulin sensitivity in humans. Acta Physiol. (Oxf.) 2018, 223, e13039. [CrossRef] [PubMed]

34. McHill, A.W.; Phillips, A.J.; Czeisler, C.A.; Keating, L.; Yee, K.; Barger, L.K.; Garaulet, M.; Scheer, F.A.; Klerman, E.B. Later circadian timing of food intake is associated with increased body fat. Am. J. Clin. Nutr. 2017, 106, 1213-1219. [CrossRef] [PubMed]

35. Akashi, M.; Soma, H.; Yamamoto, T.; Tsugitomi, A.; Yamashita, S.; Yamamoto, T.; Nishida, E.; Yasuda, A.; Liao, J.K.; Node, K. Noninvasive method for assessing the human circadian clock using hair follicle cells. Proc. Natl. Acad. Sci. USA 2010, 107, 15643-15648. [CrossRef] [PubMed]

36. Leung, M.; Tranmer, J.; Hung, E.; Korsiak, J.; Day, A.G.; Aronson, K.J. Shift Work, Chronotype, and Melatonin Patterns among Female Hospital Employees on Day and Night Shifts. Cancer Epidemiol. Biomarkers $\mathcal{E}$ Prev. 2016, 25, 830-838.

37. Laposky, A.D.; Shelton, J.; Bass, J.; Dugovic, C.; Perrino, N.; Turek, F.W. Altered sleep regulation in leptin-deficient mice. Am. J. Physiol. Regul. Integr. Comp. Physiol. 2006, 290, R894-R903. [CrossRef]

38. Sans-Fuentes, M.A.; Diez-Noguera, A.; Cambras, T. Light responses of the circadian system in leptin deficient mice. Physiol. Behav. 2010, 99, 487-494. [CrossRef]

39. Dauncey, M.J.; Brown, D. Role of activity-induced thermogenesis in twenty-four hour energy expenditure of lean and genetically obese (ob/ob) mice. Q. J. Exp. Physiol. 1987, 72, 549-559. [CrossRef] 
40. Kudo, T.; Akiyama, M.; Kuriyama, K.; Sudo, M.; Moriya, T.; Shibata, S. Night-time restricted feeding normalises clock genes and Pai-1 gene expression in the db/db mouse liver. Diabetologia 2004, 47, 1425-1436. [CrossRef]

41. Laposky, A.D.; Bradley, M.A.; Williams, D.L.; Bass, J.; Turek, F.W. Sleep-wake regulation is altered in leptin-resistant (db/db) genetically obese and diabetic mice. Am. J. Physiol. Regul. Integr. Comp. Physiol. 2008, 295, R2059-R2066. [CrossRef]

42. Roesler, W.J.; Helgason, C.; Gulka, M.; Khandelwal, R.L. Aberrations in the diurnal rhythms of plasma glucose, plasma insulin, liver glycogen, and hepatic glycogen synthase and phosphorylase activities in genetically diabetic (db/db) mice. Horm. Metab. Res. 1985, 17, 572-575. [CrossRef] [PubMed]

43. Ando, H.; Oshima, Y.; Yanagihara, H.; Hayashi, Y.; Takamura, T.; Kaneko, S.; Fujimura, A. Profile of rhythmic gene expression in the livers of obese diabetic KK-A(y) mice. Biochem. Biophys. Res. Commun. 2006, 346, 1297-1302. [CrossRef] [PubMed]

44. Kaneko, K.; Yamada, T.; Tsukita, S.; Takahashi, K.; Ishigaki, Y.; Oka, Y.; Katagiri, H. Obesity alters circadian expressions of molecular clock genes in the brainstem. Brain Res. 2009, 1263, 58-68. [CrossRef] [PubMed]

45. Hsieh, M.C.; Yang, S.C.; Tseng, H.L.; Hwang, L.L.; Chen, C.T.; Shieh, K.R. Abnormal expressions of circadian-clock and circadian clock-controlled genes in the livers and kidneys of long-term, high-fat-diet-treated mice. Int. J. Obes. (Lond.) 2010, 34, 227-239. [CrossRef]

46. Herrero, L.; Valcarcel, L.; da Silva, C.A.; Albert, N.; Diez-Noguera, A.; Cambras, T.; Serra, D. Altered circadian rhythm and metabolic gene profile in rats subjected to advanced light phase shifts. PLOS ONE 2015, 10, e0122570. [CrossRef] [PubMed]

47. Sasaki, T.; Numano, R.; Yokota-Hashimoto, H.; Matsui, S.; Kimura, N.; Takeuchi, H.; Kitamura, T. A central-acting connexin inhibitor, INI-0602, prevents high-fat diet-induced feeding pattern disturbances and obesity in mice. Mol. Brain 2018, 11, 28. [CrossRef] [PubMed]

48. Kohsaka, A.; Laposky, A.D.; Ramsey, K.M.; Estrada, C.; Joshu, C.; Kobayashi, Y.; Turek, F.W.; Bass, J. High-fat diet disrupts behavioral and molecular circadian rhythms in mice. Cell Metab. 2007, 6, 414-421. [CrossRef]

49. Mendoza, J.; Pevet, P.; Challet, E. High-fat feeding alters the clock synchronization to light. J. Physiol. 2008, 586, 5901-5910. [CrossRef]

50. Hatori, M.; Vollmers, C.; Zarrinpar, A.; DiTacchio, L.; Bushong, E.A.; Gill, S.; Leblanc, M.; Chaix, A.; Joens, M.; Fitzpatrick, J.A.; et al. Time-restricted feeding without reducing caloric intake prevents metabolic diseases in mice fed a high-fat diet. Cell Metab. 2012, 15, 848-860. [CrossRef]

51. Altarejos, J.Y.; Montminy, M. CREB and the CRTC co-activators: sensors for hormonal and metabolic signals. Nat. Rev. Mol. Cell Biol. 2011, 12, 141-151. [CrossRef]

52. Eckel-Mahan, K.L.; Patel, V.R.; de Mateo, S.; Orozco-Solis, R.; Ceglia, N.J.; Sahar, S.; Dilag-Penilla, S.A.; Dyar, K.A.; Baldi, P.; Sassone-Corsi, P. Reprogramming of the circadian clock by nutritional challenge. Cell 2013, 155, 1464-1478. [CrossRef] [PubMed]

53. Okano, S.; Hayasaka, K.; Igarashi, M.; Iwai, H.; Togashi, Y.; Nakajima, O. Non-obese early onset diabetes mellitus in mutant cryptochrome1 transgenic mice. Eur. J. Clin. Invest. 2010, 40, 1011-1017. [CrossRef] [PubMed]

54. Fustin, J.M.; Doi, M.; Yamada, H.; Komatsu, R.; Shimba, S.; Okamura, H. Rhythmic nucleotide synthesis in the liver: temporal segregation of metabolites. Cell reports 2012, 1, 341-349. [CrossRef] [PubMed]

55. Marcheva, B.; Ramsey, K.M.; Buhr, E.D.; Kobayashi, Y.; Su, H.; Ko, C.H.; Ivanova, G.; Omura, C.; Mo, S.; Vitaterna, M.H.; et al. Disruption of the clock components CLOCK and BMAL1 leads to hypoinsulinaemia and diabetes. Nature 2010, 466, 627-631. [CrossRef]

56. Lamia, K.A.; Storch, K.F.; Weitz, C.J. Physiological significance of a peripheral tissue circadian clock. Proc. Natl. Acad. Sci. USA 2008, 105, 15172-15177. [CrossRef] [PubMed]

57. Eckel-Mahan, K.L.; Patel, V.R.; Mohney, R.P.; Vignola, K.S.; Baldi, P.; Sassone-Corsi, P. Coordination of the transcriptome and metabolome by the circadian clock. Proc. Natl. Acad. Sci. USA 2012, 109, 5541-5546. [CrossRef]

58. Rudic, R.D.; McNamara, P.; Curtis, A.M.; Boston, R.C.; Panda, S.; Hogenesch, J.B.; Fitzgerald, G.A. BMAL1 and CLOCK, two essential components of the circadian clock, are involved in glucose homeostasis. PLoS Biol. 2004, 2, e377. [CrossRef] 
59. Cho, H.; Zhao, X.; Hatori, M.; Yu, R.T.; Barish, G.D.; Lam, M.T.; Chong, L.W.; DiTacchio, L.; Atkins, A.R.; Glass, C.K.; et al. Regulation of circadian behaviour and metabolism by REV-ERB-alpha and REV-ERB-beta. Nature 2012, 485, 123-127. [CrossRef]

60. Hirt, P.A.; Castillo, D.E.; Yosipovitch, G.; Keri, J.E. Skin changes in the obese patient. J. Am. Acad Dermatol 2019, 81, 1037-1057. [CrossRef]

61. Jung, S.Y.; Park, D.C.; Kim, S.H.; Yeo, S.G. Role of Obesity in Otorhinolaryngologic Diseases. Curr. Allergy Asthma Rep. 2019, 19, 34. [CrossRef]

62. Sicherer, S.H.; Sampson, H.A. Food allergy: Epidemiology, pathogenesis, diagnosis, and treatment. J. Allergy Clin. Immunol. 2014, 133, 291-307. [CrossRef]

63. McCallister, M.; Medrano, R.; Wojcicki, J. Early life obesity increases the risk for asthma in San Francisco born Latina girls. Allergy Asthma Proc. 2018, 39, 273-280. [CrossRef]

64. Tomita, Y.; Fukutomi, Y.; Irie, M.; Azekawa, K.; Hayashi, H.; Kamide, Y.; Sekiya, K.; Nakamura, Y.; Okada, C.; Shimoda, T.; et al. Obesity, but not metabolic syndrome, as a risk factor for late-onset asthma in Japanese women. Allergol. Intl.: Official J. JPN Soci. Allergol. 2019, 68, 240-246. [CrossRef] [PubMed]

65. Deng, X.; Ma, J.; Yuan, Y.; Zhang, Z.; Niu, W. Association between overweight or obesity and the risk for childhood asthma and wheeze: An updated meta-analysis on 18 articles and 73252 children. Pediatr. Obes. 2019, 14, e12532. [CrossRef] [PubMed]

66. Jiang, D.; Wang, L.; Bai, C.; Chen, O. Association between abdominal obesity and asthma: a meta-analysis. Allergy Asthma Clin. Immunol. 2019, 15, 16. [CrossRef] [PubMed]

67. Dietze, J.; Bocking, C.; Heverhagen, J.T.; Voelker, M.N.; Renz, H. Obesity lowers the threshold of allergic sensitization and augments airway eosinophilia in a mouse model of asthma. Allergy 2012, 67, 1519-1529. [CrossRef] [PubMed]

68. Farzan, S. The asthma phenotype in the obese: distinct or otherwise? J. Allergy (Cairo) 2013, 2013, 602908. [CrossRef] [PubMed]

69. Beuther, D.A.; Sutherland, E.R. Overweight, obesity, and incident asthma: a meta-analysis of prospective epidemiologic studies. Am. J. Respir. Crit. Care Med. 2007, 175, 661-666. [CrossRef]

70. Dixon, A.E.; Pratley, R.E.; Forgione, P.M.; Kaminsky, D.A.; Whittaker-Leclair, L.A.; Griffes, L.A.; Garudathri, J.; Raymond, D.; Poynter, M.E.; Bunn, J.Y.; et al. Effects of obesity and bariatric surgery on airway hyperresponsiveness, asthma control, and inflammation. J. Allergy Clin. Immunol. 2011, 128, 508-515. [CrossRef]

71. Agon-Banzo, P.J.; Sanmartin, R.; Garcia-Malinis, A.J.; Hernandez-Martin, A.; Puzo, J.; Doste, D.; Pardos, C.; Gilaberte, Y. Body mass index and serum lipid profile: Association with atopic dermatitis in a paediatric population. Australas J. Dermatol. 2020, 61, e60-e64. [CrossRef] [PubMed]

72. Loffler, H.; Aramaki, J.U.; Effendy, I. The influence of body mass index on skin susceptibility to sodium lauryl sulphate. Skin Res. Technol. 2002, 8, 19-22. [CrossRef] [PubMed]

73. Nino, M.; Franzese, A.; Ruggiero Perrino, N.; Balato, N. The effect of obesity on skin disease and epidermal permeability barrier status in children. Pediatr. Dermatol. 2012, 29, 567-570. [CrossRef] [PubMed]

74. Guida, B.; Nino, M.; Perrino, N.R.; Laccetti, R.; Trio, R.; Labella, S.; Balato, N. The impact of obesity on skin disease and epidermal permeability barrier status. J. Eur. Acad. Dermatol. Venereol. 2010, 24, 191-195. [CrossRef] [PubMed]

75. Wu, N.L.; Hsu, C.J.; Sun, F.j; Tsai, T.F. Efficacy and safety of secukinumab in Taiwanese patients with moderate to severe plaque psoriasis: Subanalysis from ERASURE phase III study. J. Dermatol 2017, 44, 1129-1137. [CrossRef]

76. Perez, M.M.; Martins, L.M.S.; Dias, M.S.; Pereira, C.A.; Leite, J.A.; Goncalves, E.C.S.; de Almeida, P.Z.; de Freitas, E.N.; Tostes, R.C.; Ramos, S.G.; et al. Interleukin-17/interleukin-17 receptor axis elicits intestinal neutrophil migration, restrains gut dysbiosis and lipopolysaccharide translocation in high-fat diet-induced metabolic syndrome model. Immunology 2019, 156, 339-355. [CrossRef] [PubMed]

77. Hussain, M.; Bonilla-Rosso, G.; Kwong Chung, C.K.C.; Bariswyl, L.; Rodriguez, M.P.; Kim, B.S.; Engel, P.; Noti, M. High dietary fat intake induces a microbiota signature that promotes food allergy. J. Allergy Clin. Immunol. 2019, 144, 157-170. [CrossRef] [PubMed]

78. Moffatt, M.F.; Gut, I.G.; Demenais, F.; Strachan, D.P.; Bouzigon, E.; Heath, S.; von Mutius, E.; Farrall, M.; Lathrop, M.; Cookson, W.; et al. A large-scale, consortium-based genomewide association study of asthma. N. Engl. J. Med. 2010, 363, 1211-1221. [CrossRef] [PubMed] 
79. Akashi, M.; Takumi, T. The orphan nuclear receptor RORalpha regulates circadian transcription of the mammalian core-clock Bmal1. Nat. Struct. Mol. Biol. 2005, 12, 441-448. [CrossRef]

80. Solt, L.A.; Kumar, N.; Nuhant, P.; Wang, Y.; Lauer, J.L.; Liu, J.; Istrate, M.A.; Kamenecka, T.M.; Roush, W.R.; Vidovic, D.; et al. Suppression of TH17 differentiation and autoimmunity by a synthetic ROR ligand. Nature 2011, 472, 491-494. [CrossRef]

81. Lo, B.C.; Canals Hernaez, D.; Scott, R.W.; Hughes, M.R.; Shin, S.B.; Underhill, T.M.; Takei, F.; McNagny, K.M. The Transcription Factor RORalpha Preserves ILC3 Lineage Identity and Function during Chronic Intestinal Infection. J. Immunol. 2019, 203, 3209-3215. [CrossRef]

82. De Grove, K.C.; Provoost, S.; Hendriks, R.W.; McKenzie, A.N.J.; Seys, L.J.M.; Kumar, S.; Maes, T.; Brusselle, G.G.; Joos, G.F. Dysregulation of type 2 innate lymphoid cells and TH2 cells impairs pollutant-induced allergic airway responses. J. Allergy Clin. Immunol. 2017, 139, 246-257. [CrossRef] [PubMed]

83. Spadaro, G.; Giurato, G.; Stellato, C.; Marone, G.; Casolaro, V. Basophil degranulation in response to IgE ligation is controlled by a distinctive circadian clock in asthma. Allergy 2020, 75, 158-168. [CrossRef] [PubMed]

84. Kim, H.K.; Kim, H.J.; Kim, J.H.; Kim, T.H.; Lee, S.H. Asymmetric expression level of clock genes in left vs. right nasal mucosa in humans with and without allergies and in rats: Circadian characteristics and possible contribution to nasal cycle. PLoS ONE 2018, 13, e0194018. [CrossRef] [PubMed]

85. Sookoian, S.; Gemma, C.; Gianotti, T.F.; Burgueno, A.; Castano, G.; Pirola, C.J. Genetic variants of Clock transcription factor are associated with individual susceptibility to obesity. Am. J. Clin. Nutr. 2008, 87, 1606-1615. [CrossRef]

86. Garaulet, M.; Lee, Y.C.; Shen, J.; Parnell, L.D.; Arnett, D.K.; Tsai, M.Y.; Lai, C.Q.; Ordovas, J.M. Genetic variants in human CLOCK associate with total energy intake and cytokine sleep factors in overweight subjects (GOLDN population). Eur. J. Hum. Genet. 2010, 18, 364-369. [CrossRef]

87. Kok, Y.Y.; Ong, H.H.; Say, Y.H. Interleukin-1 Receptor Antagonist and Interleukin-4 Genes Variable Number Tandem Repeats Are Associated with Adiposity in Malaysian Subjects. J. Obesity 2017, 2017, 4104137. [CrossRef]

88. Roula, D.; Theiler, A.; Luschnig, P.; Sturm, G.J.; Tomazic, P.V.; Marsche, G.; Heinemann, A.; Sturm, E.M. Apolipoprotein A-IV acts as an endogenous anti-inflammatory protein and is reduced in treatment-naive allergic patients and allergen-challenged mice. Allergy 2020, 75, 392-402. [CrossRef]

89. Ehlers, A.; Xie, W.; Agapov, E.; Brown, S.; Steinberg, D.; Tidwell, R.; Sajol, G.; Schutz, R.; Weaver, R.; Yu, H.; et al. BMAL1 links the circadian clock to viral airway pathology and asthma phenotypes. Mucosal. Immunol. 2018, 11, 97-111. [CrossRef]

90. Zaslona, Z.; Case, S.; Early, J.O.; Lalor, S.J.; McLoughlin, R.M.; Curtis, A.M.; O'Neill, L.A.J. The circadian protein BMAL1 in myeloid cells is a negative regulator of allergic asthma. Am. J. Physiol. Lung Cell Mol. Physiol. 2017, 312, L855-L860. [CrossRef]

91. Nakamura, Y.; Nakano, N.; Ishimaru, K.; Hara, M.; Ikegami, T.; Tahara, Y.; Katoh, R.; Ogawa, H.; Okumura, K.; Shibata, S.; et al. Circadian regulation of allergic reactions by the mast cell clock in mice. J. Allergy Clin. Immunol. 2014, 133, 568-575. [CrossRef]

92. Nakamura, Y.; Nakano, N.; Ishimaru, K.; Ando, N.; Katoh, R.; Suzuki-Inoue, K.; Koyanagki, S.; Ogawa, H.; Okumura, K.; Shibata, S.; et al. Inhibition of IgE-mediated allergic reactions by pharmacologically targeting the circadian clock. J. Allergy Clin. Immunol. 2016, 137, 1226-1235. [CrossRef] [PubMed]

93. Nakamura, Y.; Ishimaru, K.; Shibata, S.; Nakao, A. Regulation of plasma histamine levels by the mast cell clock and its modulation by stress. Sci. Rep. 2017, 7, 39934. [CrossRef] [PubMed]

94. Gill, S.; Panda, S. A Smartphone App Reveals Erratic Diurnal Eating Patterns in Humans that Can Be Modulated for Health Benefits. Cell Metab. 2015, 22, 789-798. [CrossRef] [PubMed]

95. Barnes, P.; FitzGerald, G.; Brown, M.; Dollery, C. Nocturnal asthma and changes in circulating epinephrine, histamine, and cortisol. N. Engl. J. Med. 1980, 303, 263-267. [CrossRef] [PubMed]

96. Liang, X.; Bushman, F.D.; FitzGerald, G.A. Rhythmicity of the intestinal microbiota is regulated by gender and the host circadian clock. Proc. Natl. Acad. Sci. USA 2015, 112, 10479-10484. [CrossRef] [PubMed] 
97. Depner, M.; Ege, M.J.; Cox, M.J.; Dwyer, S.; Walker, A.W.; Birzele, L.T.; Genuneit, J.; Horak, E.; Braun-Fahrlander, C.; Danielewicz, H.; et al. Bacterial microbiota of the upper respiratory tract and childhood asthma. J. Allergy Clin. Immunol. 2017, 139, 826-834. [CrossRef]

98. Fujimura, K.E.; Sitarik, A.R.; Havstad, S.; Lin, D.L.; Levan, S.; Fadrosh, D.; Panzer, A.R.; LaMere, B.; Rackaityte, E.; Lukacs, N.W.; et al. Neonatal gut microbiota associates with childhood multisensitized atopy and T cell differentiation. Nat. Med. 2016, 22, 1187-1191. [CrossRef]

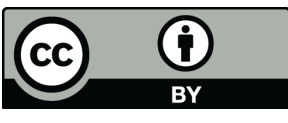

(C) 2020 by the authors. Licensee MDPI, Basel, Switzerland. This article is an open access article distributed under the terms and conditions of the Creative Commons Attribution (CC BY) license (http://creativecommons.org/licenses/by/4.0/). 